\section{IJßER}

ISSN: 2149-5939
International Journal of Social Sciences and Education Research

Online, http://dergipark.gov.tr/ijsser

Volume: 3(4), 2017

\title{
Evolving impact of the auction houses in Turkish contemporary art market
}

\author{
Güldehen Kaya ${ }^{1}$
}

Received Date: 10 / 04 / 2017

Accepted Date: 14 / $06 / 2017$

\begin{abstract}
There are vital institutions serving the production, distribution and consumption of the contemporary art works and constituting the value of art. One of those institutions, an Auction House, as being solely a commercial entity, directly affects the perception of the art value via pricing. However, market value of the art work is not necessarily a fair and sufficient indicator and does not necessarily correspond to the artist's career path. According to the artists, the perception of value attributed by that price per se, harmed the artists' reputations and careers. This research aimed to analyse the presence of Auction Houses in Turkish contemporary art market.
\end{abstract}

Keywords: Turkish contemporary art market, auction houses, value of art

\section{Introduction}

The Artworld includes many art professionals and institutions, from artists to experts, from galleries to collectors, from auction houses to museums and art fairs. Information and expertise are carried through all those agents which engage in the production, distribution and consumption of art. The Artworld communicates through a complex network connected with many types of contracts and mutual relationships without any main authority. Collaboration among agents are needed to make the art visible. With all the cultural knowledge applied to the art work, they create its value in the long run.

The institutional theory of art suggests that an artefact will be defined as art only if it is presented and made visible to the Artworld public and valorised by them. G. Dickie defines the vital elements in the Artworld emphasizing the social practice (Carroll, 2000, p. 96): "1. An artist is a person who participates with understanding in the making of a work of art. 2. A work of art is an artefact of a kind created to be presented to an Artworld public. 3. A public is a set of persons the members of which are prepared in some degree to understand an object which is presented to them. 4. The Artworld is the totality of all Artworld systems. 5. An Artworld system is a framework for the presentation of a work of art by an artist to an Artworld public."

It is necessary to understand that the evaluation of the quality of an art work is itself a cultural process and help of experts is needed who specialize in evaluating art (Bonus and Ronte, 1997). Klamer (as cited in Amariglio, Childers \& Cullenberg, 2009) suggests that art works are discursive constructs, they offer conversation and when people talk about them in the processes of valuation, evaluation and valorisation, they become cultural goods and human capital indicates that knowledge is a stock of value that generates a flow of value.

\footnotetext{
${ }^{1}$ Güldehen Kaya, Ph.D. Candidate, Işık University, Istanbul, Turkey, guldehenkaya@hotmail.com
} 
Kaya, G. (2017). Evolving impact of the auction houses in Turkish contemporary art market. International Journal of Social Sciences and Education Research, 3 (4), 1140-1146.

Figure 1. Creation, Presentation, Evaluation and Valorisation of Art within the Artworld System

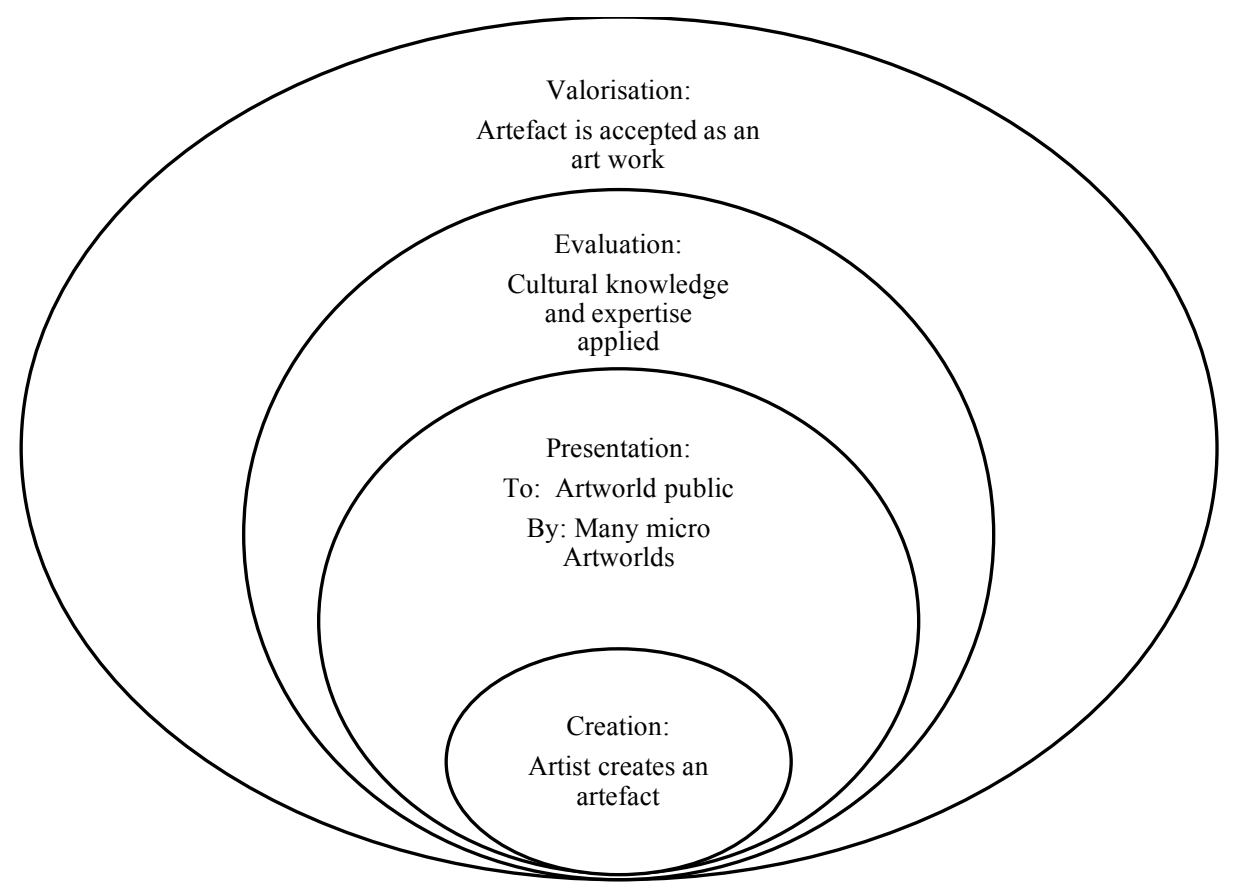

\section{Art market}

In economics, the market is a superior instrument for the allocation of scarce resources through competition. As in any market with buyers-dealers-sellers, art has a market on its own where art works are exchanged and valued in monetary terms. Art market, in the notions of capitalism, tend to describe art as a financial artefact where economic rules of supply and demand apply or art as an asset or investment of passion. As Turkish Artist Bedri Baykam states "in the long run, art is the best investment" (Adayılmaz, 2017).

Nevertheless, it is difficult and insufficient to analyse the art market compared to financial markets. Art markets are unorganized and unregulated venues because of the intuitions and social characteristics of the construction, where risk and uncertainty are diffused in every part of it. The quality of the art work is difficult to assess (Mamarbachi, Day \& Favato). Imperfection in the market becomes the tool of the competition. Consequently, it makes the potential buyers search for trust, knowledge and experience throughout the Artworld.

Emotional ambivalence or mixed feelings are part of socially ambiguous situations. In the market, social ambiguity is common, as art buyers and art sellers shift between the aesthetic sphere and commercial sphere during their transactions (Ooi, 2010). 
Kaya, G. (2017). Evolving impact of the auction houses in Turkish contemporary art market. International Journal of Social Sciences and Education Research, 3 (4), 1140-1146.

Figure 2. Art market where demand and supply meet through primary and secondary markets

\begin{tabular}{l|c|}
\cline { 2 - 2 } Demand & $\begin{array}{c}\text { Through Primary and Secondary Mar- } \\
\text { kets } \\
\text { Individual Buyers/Collectors }\end{array}$ \\
Artist's Studio & Supply \\
Galleries & Artists \\
Onstine & Re-sales \\
Art Fairs & \\
\hline
\end{tabular}

Art market operates through primary markets and secondary markets, locally and globally. Primary art market is where initial launch to the market by artist is done, through artists' studios or galleries, online channels and occasionally art fairs. Secondary art market is where auction houses and occasionally galleries function and resale of art works take place.

\section{Value of art and auction houses}

When the cultural elements are involved, it lacks a precise theory of value. Because of the unique nature of many art objects, the interpretation of market prices requires great care (Ashenfelter \& Graddy, 2002). While auction prices represent the monetary value of art works, it comes with a complex and subjective set of beliefs that is based on past, present and future prices, and individual tastes and fashion (Kraussl, 2014).

The financialization of art involves a definitional struggle between two groups of actors, the financial community and the Artworld, where each draw upon their own evaluation practices (Velthuis \& Coslor, 2012). Financial community prefers auction houses as their practices are similar to financial markets where data and liquidity are provided. On the other hand, Artworld does not accept art as a financial or commercial object speculatively traded. Rather, art is considered as a unique cultural object which its value is determined throughout the years, preferably sold to a collector or a museum who will safeguard and keep away from reselling.

Many researches have been done to understand the dynamics of the art market. Two major obstacles in analysing the art market are heterogeneity of art works and infrequency of trading. Primary market sale prices are not announced. Only, repeat sale auction prices are reliable and available and can be used as a data base for art indices that are created to follow the market's performance.

Auction Houses are commercial entities where art pieces are exchanged and valued in monetary terms. They affect the perception of the art value via pricing and expected to give confidence to the buyer and seller. Pre-sale catalogues give the information about the works, also low-high price estimate ranges. The convention in art auctions is that the reserve price is set at or below the auctioneer's low estimate. Auction records alone do not reflect the entire market and whether auction prices are biased upwards or downward is not clear (Agnello, 2002). Turkish collector Can Elgiz thinks that "even if you have direct relationship with the artist, it is still favourable to buy in the auctions. To be registered as an auction sale is important locally and globally because it reflects the true value of the art work" (“Çağdaş Sanatın İzinden”, 2017). 
Kaya, G. (2017). Evolving impact of the auction houses in Turkish contemporary art market. International Journal of Social Sciences and Education Research, 3 (4), 1140-1146.

Table 1. Advantages and disadvantages of auction houses

\begin{tabular}{|c|c|}
\hline Advantages & Disadvantages \\
\hline Provide transparency, liquidity and archiving. & Don't represent or protect an artist's career. \\
\hline $\begin{array}{l}\text { Provide alternative works of an artist or a spe- } \\
\text { cific period for collectors. }\end{array}$ & $\begin{array}{l}\text { Pre-sale estimates usually determine a range below the } \\
\text { artist's selling price in order to attract the bidders. }\end{array}$ \\
\hline Show immediate results. & Main objective is to sell at a best bid. \\
\hline $\begin{array}{l}\text { Take away the privilege of the closed society } \\
\text { associated with small numbers of buyers and } \\
\text { sellers and make it public. }\end{array}$ & $\begin{array}{l}\text { There is no close and long-term relationship with the } \\
\text { collectors as it is usually the case with the galleries. }\end{array}$ \\
\hline $\begin{array}{l}\text { Easy channel for newcomers to buy/sell or to } \\
\text { understand the art market. }\end{array}$ & $\begin{array}{l}\text { The art work to be sold is not necessarily the master- } \\
\text { piece of an artist. }\end{array}$ \\
\hline $\begin{array}{l}\text { Auction catalogues besides experts provide } \\
\text { sufficient information on the art works. }\end{array}$ & $\begin{array}{l}\text { Although auction seems openly executed, there are } \\
\text { usually hidden relations between some bidders for the } \\
\text { manipulation purposes. }\end{array}$ \\
\hline $\begin{array}{l}\text { Less intimating to buy compared to galleries, } \\
\text { no prior relationship is needed. }\end{array}$ & $\begin{array}{l}\text { There is a possibility to bid higher if a buyer gets car- } \\
\text { ried away by the fast and dynamic sentiment of the } \\
\text { auction. }\end{array}$ \\
\hline Buyers are not stressed to do any trade. & $\begin{array}{l}\text { As the reason, why the seller wants to dispose the art } \\
\text { work is unknown, any hidden agenda increases the risk } \\
\text { and uncertainty. }\end{array}$ \\
\hline $\begin{array}{l}\text { A good name of an auction house is a kind of } \\
\text { endorsement and approval of the good value of } \\
\text { the art work. }\end{array}$ & $\begin{array}{l}\text { Bidders can cause an illusion of the increase of the } \\
\text { price of the art work. If they bid higher and higher, } \\
\text { they push the market higher. This is also how specula- } \\
\text { tors perform for their own interests. }\end{array}$ \\
\hline $\begin{array}{l}\text { Give a check mechanism of the price for a } \\
\text { buyer observing other potential buyers and } \\
\text { also the artist's primary market selling price. }\end{array}$ & $\begin{array}{l}\text { There are commissions to be collected from both seller } \\
\text { and buyer. Also, VAT will be added to the hammer } \\
\text { price. }\end{array}$ \\
\hline \multicolumn{2}{|l|}{$\begin{array}{l}\text { Give opportunity to show the buyer's success } \\
\text { with media attention. }\end{array}$} \\
\hline \multicolumn{2}{|l|}{$\begin{array}{l}\text { If a buyer wants anonymity, it is possible to } \\
\text { hide the identity by joining the auction through } \\
\text { the phone or by a representative. }\end{array}$} \\
\hline \multicolumn{2}{|l|}{$\begin{array}{l}\text { Auction is a social gathering full of action, } \\
\text { watching the auctioneer managing the senti- } \\
\text { ment. }\end{array}$} \\
\hline $\begin{array}{l}\text { Buyer is free to resell anytime as there is no } \\
\text { protocol restricting the sale. }\end{array}$ & \\
\hline
\end{tabular}

Auction prices show the reconciled opinion on the market value of that art work on that day. Timing, location, publicity, commissions and competition are the elements surrounding the sale, as well as the history of ownership or provenance (Agnello, 2002). A. Karadeniz (founder of Beyaz Auction House) claims "we are extremely careful on pricing. We use worldwide accepted price ranges. The pricing is based on the fair evaluation not seller or artists claim. Auction houses 
Kaya, G. (2017). Evolving impact of the auction houses in Turkish contemporary art market. International Journal of Social Sciences and Education Research, 3 (4), 1140-1146.

are not decreasing prices, they balance the prices. Inflated prices are a main issue in the sector" (Vural, 2016, February). As art market is about today, an art work not performing well today does not indicate that it will not in the future. The cultural significance of that art work will not be determined that day but through time.

The imbalance in the market affects the artist and their sales, at most. When an advertised item goes unsold at auction, its future value will be affected. Such items are said to be "burned" and possibly lose value in subsequent auctions. Potential buyers with no cultural capital and not equipped with the information provided by the Artworld, will evaluate the art work solely with its price. Short term trading and price decreases signalling lack of quality harm the self-esteem of artists.

\section{The artist}

There are many complicated factors affecting the artist's career. The status of art and artists are acquired through the social system and processes of internalisation (Ooi, 2010).

Figure 3. Factors affecting the artist's career

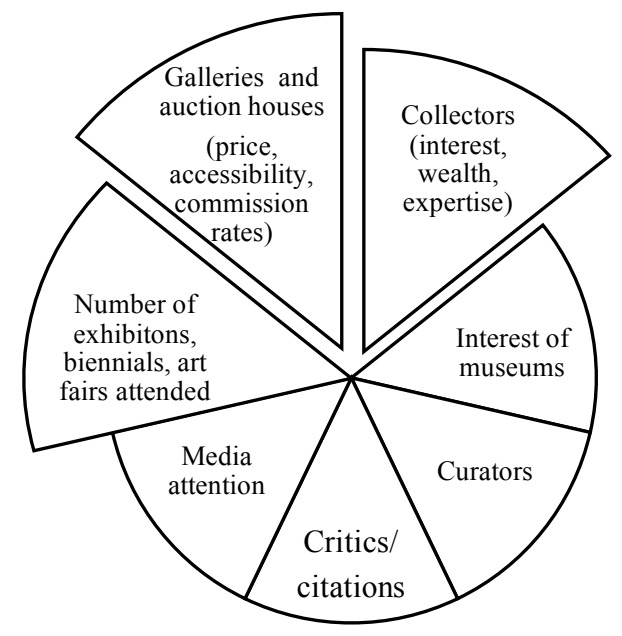

It is vital to note that time is the crucial factor embedded in this process. The artist's career is also affected by her/his vision, ideas and content of the work, number of mediums he/she works, production rate, experience, education, luck, fame, personal life, any prizes she/he won and credibility. In addition, it is affected by the past, present and future prices, tastes and fashion, trends, advertising, cultural capital, social and economic prosperity, income distribution, innovation, online markets, country's cultural strategy, political changes, legal and fiscal regulation, price of alternative investments, globalization and so on. A Turkish artist (name disguised) claims that "As an artist, what I can do by myself in Turkish art is limited. With a good team and established institutions, I can be on a fair career path".

\section{Turkish contemporary art market}

Turkish Contemporary Art Market is almost 40 years old, unexperienced but dynamic. Istanbul is the main platform for galleries, art fairs, auction houses and international organizations. There are many contemporary art galleries, few auction houses. Auction houses are the main 
Kaya, G. (2017). Evolving impact of the auction houses in Turkish contemporary art market. International

Journal of Social Sciences and Education Research, 3 (4), 1140-1146.

venues to come across with the masterpieces of the Turkish art history. Nevertheless, the specialization of contemporary art in the auction houses is new. As it is an emerging market, auction houses attract speculators and occasional buyers besides collectors. As T. Artam (founder of Antik A.Ş., Auction House) states "any new auction brings energy and effort to the market" (Adayılmaz, 2017).

There is an ongoing issue between auction houses and artists on the incommensurate valuation of the art works. Artists are disturbed by the policies of the auction houses where their works are subject to speculative trading. Although market value is not necessarily a fair and sufficient indicator and does not necessarily correspond to the artist's career path, that perception of value attributed by that price per se, harms the artists' reputations and careers. B. Baykam warns that "if there are no artists, there will be no collectors, no museums, no critics, no writers, no curators, no auctioneers" (Vural, 2016, January). In Turkey, "Artist Resale Right" which is the right granted to artists or their heirs, to receive a fee on the resale of their works of arts, is enacted in 2006. It gives responsibility to the buyer and the auction house, legally, to compensate the artist. Unfortunately, it is not yet in practice.

In auctions, the reserve price is set at or below the auctioneer's low estimate and they act in favour of some collectors, that the artist's art works are sold undervalued. T. Artam states that "the work is offered under the market price, in auctions. It is the same everywhere in the world (Vural, 2016, February). In addition, the duration between the launch in the primary market and reselling in the auction house is significantly short. It creates more uncertainty, doubt and distrust of the auction mechanism.

\section{Conclusion}

Throughout the art history, the auction houses have been main sources to reach the unique and unattainable art works, not platforms for speculation and trade. The contemporary art era brought abundant supply behaved as a financial commodity for the buyers at a market price degrading its artistic and social values.

Artworld has its own norms, not written, and with no absolute truth. It is widely dependent on trust, to function properly. If any component of the Artworld is incompetent executing its responsibilities, the system will deteriorate in creating value. Any small volatility or violation of trust will consequently create big fluctuations. Art markets will operate properly by art institutions' collaboration and long-term vision. If the art work is to be considered as an investment tool, it should be a long-term investment by diffusing the high transaction costs such as auction fees, insurance and handling costs throughout the years.

Galleries are the crucial institutions on the valuation of the art works. Control over the market is important to galleries. They do not prefer to sell to buyers who will resell in the secondary market. Once an artist's work goes to auction, the prices are observable to the public, and anyone, collectors or traders, can buy it. It is not uncommon for gallery owners to bid on their artist's work at the auction to control the market price. As T. Artam states "galleries should protect their artists in the secondary market. It the artist is in the auction with a fair price, galleries bid as a buyer and show the faith to the artist and the collectors of that artist. In this case, collectors trust both the gallery and the artist that if he wants to sell the work in the future, it is doable" (Vural, 2016, February). 
Kaya, G. (2017). Evolving impact of the auction houses in Turkish contemporary art market. International Journal of Social Sciences and Education Research, 3 (4), 1140-1146.

Auctions should offer one or two works of the same artist. However, they might be offering more works that will damage the artists career and consequently, will disturb the collectors of the artist. Auction houses may ask the artist and the gallery's opinion about the offer price. Otherwise it damages the gallery-artist-collector pricing system. If collectors the art work and galleries sell it at a fair price, and if the artists don't sell the works directly to auction houses and cooperate with galleries, there will be less motive for speculation.

"Young" Turkish contemporary art market will show its potential if the institutions become professional, established and trustworthy. Any beneficial activity for art's sake will contribute to art in return. Only this way, it will have strength to continue functioning during any crisis or fluctuation. When the art and money relation is spread over the years, art will not be defeated to any imposition coming from the market. Art, by nature, will not compromise.

\section{References}

Adayılmaz, E.Ş. (2017, March). Müzayedeye Çıkmak ya da Düşmek; İşte Bütün Mesele Bu. Istanbul Art News 40, Piyasa. p.10-12.

Agnello, R. J.(2002). Investment Returns and Risk for Art: Evidence from Auctions of American Paintings. Eastern Economic Journal 28(4), 443-463.

Amariglio, J., J.W. Childers \& S.E. Cullenberg (2009) (Eds.) Sublime Economy, On the Intersection of Art and Economics (pp.250-257). New York: Routletge.

Ashenfelter, O. \& Graddy, K. (2002). Art Auctions: A Survey of Empirical Studies, Working Paper 8997, Retrieved From National Bureau of Economic Research website. http:// www.nber.org/papers/w8997.pdf.

Bonus H. \& Ronte, D. (1997). Credibility and Economic Value in the Visual Arts. Journal of Cultural Economics 21, 103-118.

Carroll, N. (2000). Theories of Art Today. Wisconsin:The University of Wisconsin Press.

Çağdaş Sanatın İzinden (2017, March-April). Artam Global Art and Design, pp. 118-119.

Kräussl, R. (2014). Art as an Alternative Asset Class: Risk and Return Characteristics of the Middle Eastern \& Northern African Art Markets. dx.doi.org/10.2139/ssrn.2518131

Mamarbachi, R., Day M., Favato, G. Marc Day \& Giampiero Favato. Art as an alternative investment asset. http://dx.doi.org/10.2139/ssrn.1112630

McAndrew, Clare. The Art Market 2017, An Art Basel \& UBS Report. Retrieved from Art Basel Web Site. http://www.artbasel.com/theartmarket

Ooi, Can-Seng (2010). Cacophony of Voices and Emotions: Dialogic of Buying and Selling Art. Culture Rebound, Volume: 2, 347-364.

Velthuis, O., Coslor B. (2012). The Financialization of Art. In K.K. Cetina, A. Preda (Eds.) The Oxford HandBook of The Sociology of Finance (pp. 472-473). Oxford: Oxford University Press,

Vural, E. (2016, January). Sanatçı Yoksa Hiç Kimse yok. Istanbul Art News 27, p.12.

Vural, E. (2016, February). Kolektif Hezeyan. Istanbul Art News 28, Piyasa. p. 6. 